Murat Aksit*, Giray Bozkaya, Nuriye Uzuncan, Sibel Bilgili, Can Ozlu and Merve Zeytinli Aksit

\title{
Relationship between JAK2-V617F mutation and hematologic parameters in Philadelphia-negative chronic myeloproliferative neoplasms
}

\section{[Philadelphia-negatif kronik miyeloproliferatif neoplazilerde JAK2-V617F mutasyonu ile hematolojik parametreler arasındaki ilişki]}

https://doi.org/10.1515/tjb-2020-0267

Received November 28, 2019; accepted October 1, 2020; published online November 2, 2020

\section{Abstract}

Objectives: We aimed to investigate the prevalence of JAK2-V617F mutation and its association with hematologic parameters in polycythemia vera(PV), essential thrombocytosis(ET) and primary myelofibrosis(PMF) patients who have been tested for the mutation.

Methods: We retrospectively reviewed the records of 168 patients (82 males and 86 females) who were tested for JAK2-V617F mutation upon request of Hematology Clinic. JAK2-V617F mutation status, white blood cell (WBC) counts,

\footnotetext{
*Corresponding author: Murat Aksit, University of Health Sciences, Tepecik Training and Research Hospital, Medical Biochemistry Department, Yenisehir, Gaziler Street No:468, Konak, 35170, Izmir, Turkey, Phone: +90 537542 5992, Phone (business): +90 23244435 60, Fax: +90 23243307 56, E-mail: murataksit3545@gmail.com. https://orcid.org/0000-0003-2106-9130

Giray Bozkaya, Nuriye Uzuncan and Sibel Bilgili, Bozyaka Training and Research Hospital, Medical Biochemistry Department, Izmir, Turkey, E-mail: giraybozkaya@yahoo.com (G. Bozkaya), n_uzuncan@yahoo.com (N. Uzuncan), sibel.bilgili@yahoo.com (S. Bilgili). https://orcid.org/0000-0001-6714-9844 (S. Bilgili) Can Ozlu, Bozyaka Training and Research Hospital, Hematology Department, Izmir, Turkey, E-mail: cozlu20@gmail.com

Merve Zeytinli Aksit, Tepecik Training and Research Hospital, Medical Biochemistry Department, Izmir, Turkey,

E-mail: mervezeyt@gmail.com
}

platelet (PLT) counts, hemoglobin (Hb), hematocrit (Hct) levels and demographics of the patients were recorded.

Results: JAK2-V617F mutation was detected in $55.9 \%$ of the 168 patients. The mutation was observed in $58.2 \%$ of PV cases, in $54.4 \%$ of ET and in $54.5 \%$ of PMF cases. All patients were divided into two groups: mutation positive and negative. Age, WBC and PLT levels were significantly higher in mutation positive group ( $\mathrm{p}<0.05)$. Age, WBC, $\mathrm{Hb}$, Hct and PLT counts in PV cases with JAK2-V617F mutation, age and WBC counts in PMF cases with JAK2-V617F mutation were found to be significantly higher compared to mutation negative patients $(\mathrm{p}<0.05)$.

Conclusion: JAK2-V617F mutation is a very important parameter in diagnostic and prognostic evaluation. Thus, every patient suspected of having a myeloproliferative neoplasm should be screened for JAK2-V617F mutation.

Keywords: janus kinase 2; mutation; polycythemia vera; primary myelofibrosis; thrombocytosis.

\section{öz}

Amaç: Mutasyon testi yapılan polisitemi vera (PV), esansiyel trombositoz (ET) ve primer miyelofibroz (PMF) hastalarnda JAK2-V617F mutasyonunun prevalansını ve hematolojik parametrelerle ilişkisini araştırmayı amaçladık.

Gereç ve Yöntem: Hematoloji Kliniğinin talebi üzerine JAK2-V617F mutasyonu için test edilen 168 hastanın (82 erkek ve 86 kadın) kayıtlanı retrospektif olarak incelendi. Hastaların JAK2-V617F mutasyon durumu, beyaz kan hücresi (WBC) 
sayllan, trombosit (PLT) sayllan, hemoglobin (Hb), hematokrit (Hct) düzeyleri ve demografik bilgileri kaydedildi.

Bulgular: JAK2-V617F mutasyonu 168 hastanin \% 55.9' unda tespit edildi. Mutasyon PV vakalarının \% 58,2'sinde, ET vakalarının \% 54,4'ünde ve PMF vakalarının \% 54,5' inde görülmüştür. Tüm hastalar iki gruba ayrıldı: mutasyon pozitif ve negatif. Yaş, WBC ve PLT düzeyleri mutasyon pozitif grupta anlamlı yüksekti $(\mathrm{p}<0.05)$. JAK2-V617F mutasyonu olan PV olgularında yaş, WBC, $\mathrm{Hb}$, Hct ve PLT sayıları, JAK2-V617F mutasyonu olan PMF olgularında yaş ve WBC sayıları mutasyon negatif hastalara göre anlamlı olarak yüksek bulundu ( $\mathrm{p}<0.05)$.

Sonuç: JAK2-V617F mutasyonu, tanısal ve prognostik değerlendirmede çok önemli bir parametredir. Bu nedenle, miyeloproliferatif neoplazm olduğundan şüphelenilen her hasta JAK2-V617F mutasyonu açısından taranmalıdır.

Anahtar Kelimeler: janus kinaz 2; mutasyon; polisitemia vera; primer miyelofibrozis; trombositoz.

\section{Introduction}

Myeloproliferative neoplasms (MPN) are characterized by the clonal, uncontrolled proliferation of one or more myeloerythroid cell lineages in bone marrow, and the rise in the number of mature and immature cells in the peripheral blood. Polycythemia vera (PV), essential thrombocytosis (ET), and primary myelofibrosis (PMF) are Philadelphia-negative MPN [1]. Key features of MPN are; increased red blood cells in PV, increased platelet count in ET, and bone marrow fibrosis in PMF. These three diseases share common features like hypercellularity in bone marrow, an increased risk for thrombosis, hemorrhages, and leukemic transformation [2].

Janus kinase 2(JAK2) is a cytoplasmic protein, JAK2 gene is located on the short arm of chromosome 9 [1, 3]. The substitution of valine for phenylalanine at position 617 occurs in the $\mathrm{JH} 2$ domain at exon 14 of the JAK2 gene [4]. The mutation is known as V617F causes tyrosine phosphorylation activity which leads to hypersensitivity to cytokines. This mutation makes the hematopoietic precursor cells hypersensitive to growth factors [5]. The effect explains the excessive increase in one or more hematologic cell lines seen in MPN. JAK2 mutation has been shown $90-95 \%$ in PV, $50-70 \%$ in ET, and $40-50 \%$ in PMF [6]. From this aspect, said mutation is a substantial diagnostic tool for chronic MPN [7]. World Health Organization (WHO) listed the presence of JAK2-V617F mutation among PV, ET and PMF diagnosis criteria in 2008 and the association between the presence of the mutation and disease severity was established $[1,8]$.
The haemostatic complications such as vascular thrombosis and hemorrhages severely affect the survival time of patients with MPN [9]. There is an unreasonable tendency in patients with PV and ET to both haemorrhage and thrombotic complications, each of which carries a high risk of morbidity and mortality [10]. The percentage of thrombotic complications in PV, ET, and PMF has been reported to be $30-50 \%, 11-45 \%$, and $7.2-11 \%$, respectively [10-13]. Haemorrhage symptoms in MPN have been associated with pronounced thrombocytosis (platelet count $>1000 \times 109 / 1)$ [10]. Hemorrhage complications are less visible than thrombotic complications in PV. Thrombotic complications were reported in $2.1 \%$ of $\mathrm{PV}$ patients and in $22.9 \%$ of ET patients $[14,15]$. Studies have shown that leukocytosis is an independent risk factor for arterial thrombosis in PV and ET patients [16, 17].

We aimed to investigate the prevalence of JAK2-V617F mutation which contributes to early diagnosis of Philadelphia-negative MPN and the relation between the mutation and some hematologic parameters.

\section{Materials and methods}

Total of 168 MPV patients (PV, ET, and PMF) who were diagnosed and followed up according to MPN diagnosis criteria of WHO in Izmir Bozyaka Training and Research Hospital, Hematology Clinic were included in the study. The inclusion criteria for the study were: newly diagnosed, not previously treated, and not having a comorbid disease. The patients previously diagnosed and treated elsewhere, and having a comorbid disease were rejection criteria of our study. Demographics, white blood cell (WBC), hemoglobin (Hb), hematocrit (Hct), platelet (PLT) counts at the time of diagnosis and JAK2-V617F mutation status of the patients were investigated retrospectively. DNA samples were purified from $200 \mu \mathrm{l}$ blood samples using the EZ1 DNA Blood $200 \mu \mathrm{L}$ Kit in Advanced XL (Qiagen, USA) instrument. In the Real-Time Polymerase Chain Reaction (PCR) method, JAK2 MutaScreen Kit \& Reference Scale Assay (Ipsogen, Qiagen Strasse 1, 40724 Hilden, Germany) kit was used. JAK2 (wild-type) and JAK2 V617F (mutant) alleles in genomic DNA were detected by allelic discrimination method using two specific Tagman probes. These probes are marked with different allele specific fluorescent dyes (FAM or VIC). The mutant allele (V617F) was detected with the probe labeled FAM (483-533) and the wild-type allele was detected with the probe labeled VIC (533-568). The fluorescence intensity of the dyes specific to the two alleles was measured in the Rotor Gene-Q (Qiagen, Hilden, Germany) device by Real-Time PCR method. Positive control (100\% V617F), negative control $(0 \%$ V617F), cut-off sample (2\% V617F) and 5 standards (5, 12.5, 31, 50, 78\% $\mathrm{V} 617 \mathrm{~F}$, respectively) were used. Results were expressed as a percent of JAK2 V617F in total JAK2. The results higher than the cut-off value were considered mutant. Complete blood cell count parameters were analyzed using automated blood cell counter BC5800 (Mindray, China). 
Statistical Package for Social Sciences (SPSS) 21.0 (IBM, ABD) was used for statistical analyses and calculations. The normality of the quantitative data was assessed by the Kolmogorov-Smirnov test. Student-t test was used for intergroup comparison of normally distributed variables in independent groups, descriptive statistics were shown as mean \pm standard deviation (SD). For intergroup comparison of variables that are not normally distributed, the Mann-Whitney $U$ test was done, descriptive statistics were shown as median (minimum value-maximum value). The relationship between normally distributed variables was analyzed by the Pearson correlation test, and the relationship between non-normally distributed variables was analyzed with the Spearman correlation test. $p<0.05$ was considered statistically significant.

\section{Results}

168 MPN patients screened for JAK2-V617F mutation were included in the study. Of the patients involved, 90 (53.6\%) had ET, 67 (39.9\%) had PV and 11 (6.5\%) had PMF. The mean age of the patient groups was $60.5 \pm 17.9$, 63.0 \pm 15.6 , and $62.0 \pm 9.9$ in ET, PV, and PMF, respectively. Eighty two $(48.8 \%)$ of the patients were male, $86(51.2 \%)$ were female. Upon assessment of all cases, no statistically significant association was observed between the presence of this mutation and gender.

JAK2-V617F mutation was found in 94 (55.9\%) of the patients assessed. This mutation was present in $39(58.2 \%)$ of 67 patients diagnosed with PV, 49 (54.4\%) of 90 patients diagnosed with ET, and 6 (54.5\%) of 11 patients diagnosed with PMF (Figure 1).

All MPN patients were divided into two groups according to the presence of the mutation. Age, WBC, and PLT were observed to be significantly higher in the group with mutation; no statistically significant difference was found for other parameters (Table 1). While significant association was noted between JAK2-V617F mutation results and age (r:0.274;p<0.001), WBC (r:0.145;p:0.047), PLT (r:0.581;p<0.001), no significant association was found for $\mathrm{Hb}$ and Hct.

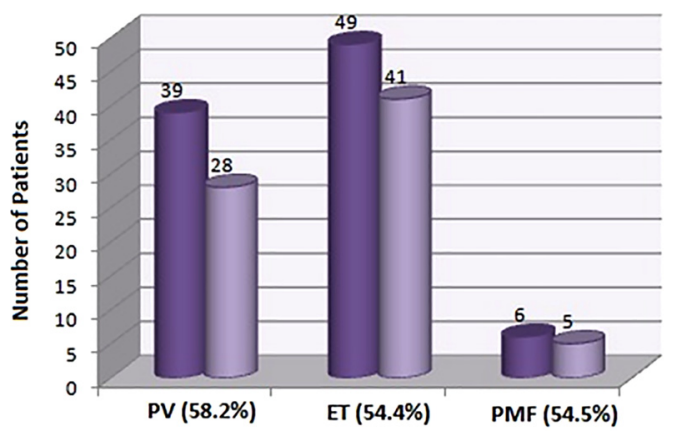

autant aWild-type

Figure 1: Presence of JAK2-V617F mutation in patient groups.
Table 1: Studies investigating the effect of the presence of JAK2-V617F mutation on age and hematologic parameters in MPN patients.

\begin{tabular}{|c|c|c|c|}
\hline & Mutant & Wild-type & p-Value \\
\hline \multirow[t]{2}{*}{ Karkucak et al. [18] } & $(n=89)$ & $(n=59)$ & \\
\hline & $\mathrm{F} / \mathrm{M}(53 / 36)$ & $\mathrm{F} / \mathrm{M}(33 / 26)$ & \\
\hline Age, year & $62.17 \pm 12.85$ & $50.03 \pm 14.28$ & $<0.001$ \\
\hline $\mathrm{WBC}, 10^{3} / \mu \mathrm{L}$ & $12.9 \pm 5.6$ & $11.1 \pm 3.8$ & 0.021 \\
\hline $\mathrm{Hb}, \mathrm{g} / \mathrm{dL}$ & $15.56 \pm 3.01$ & $14.22 \pm 3.07$ & 0.010 \\
\hline \multirow[t]{2}{*}{$\mathrm{PLT}, 10^{3} / \mu \mathrm{L}$} & 683 & 968 & 0.017 \\
\hline & $(124-2763)^{\star}$ & $(155-2900)^{*}$ & \\
\hline \multirow[t]{2}{*}{ Ünal et al. [19] } & $(n=30)$ & $(n=171)$ & \\
\hline & $\mathrm{F} / \mathrm{M}(4 / 26)$ & $\mathrm{F} / \mathrm{M}(23 / 148)$ & \\
\hline Age, year & $65.4 \pm 15.7$ & $48.5 \pm 16.3$ & 0.001 \\
\hline \multirow[t]{2}{*}{ WBC, $10^{3} / \mu \mathrm{L}$} & 12.50 & 8.29 & 0.06 \\
\hline & $(5.96-32.50)^{\star}$ & $(2.79-41.05)^{\star}$ & \\
\hline $\mathrm{Hb}, \mathrm{g} / \mathrm{dL}$ & $14.5(9.7-22.8)^{\star}$ & $16.4(7.2-20.6)^{\star}$ & 0.207 \\
\hline Hct, \% & $46.0(31.6-68.9)^{\star}$ & $48.8(24-64.3)^{\star}$ & 0.845 \\
\hline $\mathrm{PLT}, 10^{3} / \mu \mathrm{L}$ & $675(73-2112)^{\star}$ & $242(25-1756)^{\star}$ & 0.001 \\
\hline \multirow[t]{2}{*}{ Speletas et al. [20] } & $(n=119)$ & $(n=47)$ & \\
\hline & F/M (61/58) & F/M (24/23) & \\
\hline Age, year & $61.7(24-88)^{\star}$ & $56.1(29-87)^{\star}$ & 0.02 \\
\hline WBC, $10^{3} / \mu \mathrm{L}$ & $11.3 \pm 5.2$ & $10.9 \pm 6.1$ & 0.44 \\
\hline $\mathrm{Hb}, \mathrm{g} / \mathrm{dL}$ & $14.9 \pm 2.6$ & $13.8 \pm 3$ & $<0.01$ \\
\hline Hct, \% & $46 \pm 8.5$ & $42.4 \pm 8.6$ & $<0.01$ \\
\hline $\mathrm{PLT}, 10^{3} / \mu \mathrm{L}$ & $757 \pm 359$ & $819 \pm 424$ & 0.13 \\
\hline \multirow[t]{2}{*}{ Our study } & $(n=94)$ & $(n=74)$ & \\
\hline & $\mathrm{F} / \mathrm{M}(51 / 43)$ & $\mathrm{F} / \mathrm{M}(35 / 39)$ & \\
\hline Age, year & $62.2 \pm 16.1$ & $54.4 \pm 16.2$ & 0.002 \\
\hline \multirow[t]{2}{*}{ WBC, $10^{3} / \mu \mathrm{L}$} & 11.2 & 8.5 & $<0.001$ \\
\hline & $(1.4-112.4)^{\star}$ & $(4.2-27.4)^{\star}$ & \\
\hline $\mathrm{Hb}, \mathrm{g} / \mathrm{dL}$ & $14.8 \pm 3.7$ & $14.5 \pm 3.1$ & 0.527 \\
\hline Hct, \% & $45.1 \pm 9.3$ & $44.9 \pm 10.5$ & 0.966 \\
\hline $\mathrm{PLT}, 10^{3} / \mu \mathrm{L}$ & $626.8 \pm 315.2$ & $512.7 \pm 358.1$ & 0.030 \\
\hline
\end{tabular}

* : median (min-max), others mean \pm SD. F/M, Female/Male.

For PV patients; mean age, WBC, Hb, Hct and PLT counts were higher among mutation positive group, statistical significance was achieved (Table 2). Significant association was found between mutation status of PV patients and age (r:0.321;p:0.046), WBC ( $\mathrm{r}: 0.527 ; \mathrm{p}<0.001)$, Hb (r:0.592;p<0.001), Hct $\quad(\mathrm{r}: 0.415 ; \mathrm{p}<0.001)$ PLT (r:0.581;p<0.001).

Despite higher WBC, Hb, Hct, and PLT for mutation positive ET patients; no statistically significant difference was observed between two groups. The group with the mutation had a higher mean age and a significant difference was noted (Table 3). For ET patients, a significant association was noted between JAK2 mutation status and age (r:0.270;p:0.010), Hct (r:0.235;p:0.026); WBC, Hb, PLT counts were not found be significantly associated with mutation results.

PMF patients with the mutation had higher $\mathrm{Hb}$, Hct, and PLT; there was no statistically significant difference between the two groups. A significant difference was 
Table 2: Studies investigating the effect of the presence of JAK2-V617F mutation on age and hematologic parameters in PV patients.

\begin{tabular}{|c|c|c|c|}
\hline & Mutant & Wild-type & p-Value \\
\hline \multirow[t]{2}{*}{ Speletas et al. [20] } & $(n=35)$ & $(n=8)$ & \\
\hline & F/M (15/19) & $\mathrm{F} / \mathrm{M}(2 / 6)$ & \\
\hline Age, year & $63.6(45-82)^{\star}$ & $60.7(37-75)^{\star}$ & 0.77 \\
\hline WBC, $10^{3} / \mu \mathrm{L}$ & $11.5 \pm 3.3$ & $9.2 \pm 2.5$ & 0.04 \\
\hline $\mathrm{Hb}, \mathrm{g} / \mathrm{dL}$ & $17.9 \pm 1.6$ & $18.9 \pm 1.02$ & 0.26 \\
\hline Hct, \% & $56.1 \pm 5.0$ & $57.4 \pm 2.7$ & 0.44 \\
\hline $\mathrm{PLT}, 10^{3} / \mu \mathrm{L}$ & $521 \pm 180$ & $285 \pm 109$ & 0.09 \\
\hline Duletic et al. [21] & $(n=36)$ & $(n=5)$ & \\
\hline WBC, $10^{3} / \mu \mathrm{L}$ & $11.6 \pm 2.9$ & $8.9 \pm 2.3$ & 0.064 \\
\hline $\mathrm{Hb}, \mathrm{g} / \mathrm{dL}$ & $17.7 \pm 1.39$ & $16.84 \pm 1.25$ & 0.21 \\
\hline \multirow[t]{2}{*}{$\mathrm{PLT}, 10^{3} / \mu \mathrm{L}$} & 546.5 & 185 & 0.006 \\
\hline & $(135-1224)^{\star}$ & $(173-307)^{\star}$ & \\
\hline Demir et al. [22] & $(n=24)$ & $(n=4)$ & \\
\hline WBC, $10^{3} / \mu \mathrm{L}$ & 14 & 7.365 & 0.358 \\
\hline $\mathrm{Hb}, \mathrm{g} / \mathrm{dL}$ & $17.3 \pm 2.3$ & $17.8 \pm 0.8$ & 0.731 \\
\hline Hct, \% & $53.1 \pm 8.2$ & $50.7 \pm 1.3$ & 0.411 \\
\hline $\mathrm{PLT}, 10^{3} / \mu \mathrm{L}$ & 545 & 233 & 0.396 \\
\hline \multirow[t]{2}{*}{ Our study } & $(n=39)$ & $(n=28)$ & \\
\hline & F/M (20/19) & $\mathrm{F} / \mathrm{M}(1 / 27)$ & \\
\hline Age, year & $61.8 \pm 12.2$ & $54.1 \pm 18.7$ & 0.046 \\
\hline \multirow[t]{2}{*}{ WBC, $10^{3} / \mu \mathrm{L}$} & 11.0 & 7.5 & $<0.001$ \\
\hline & $(1.5-34.4)^{\star}$ & $(4.3-27.4)^{\star}$ & \\
\hline $\mathrm{Hb}, \mathrm{g} / \mathrm{dL}$ & $19.2 \pm 0.9$ & $17.0 \pm 1.9$ & $<0.001$ \\
\hline \multirow[t]{2}{*}{ Hct, \% } & 56.6 & 52.8 & 0.001 \\
\hline & $(50.1-65.0)^{\star}$ & $(38.7-66.4)^{\star}$ & \\
\hline $\mathrm{PLT}, 10^{3} / \mu \mathrm{L}$ & $415.7 \pm 202.1$ & $198.0 \pm 62.8$ & $<0.001$ \\
\hline
\end{tabular}

* : median (min-max), others mean \pm SD. F/M, Female/Male.

observed between mean age and WBC counts between two groups (Table 4). For PMF patients, no association was observed between mutation status and age, $\mathrm{Hb}$, Hct, and PLT count; only WBC count (r:0.752;p:0.008) was found to be significantly associated with mutation results.

\section{Discussion}

JAK2-V617F mutation of hematopoietic stem cell renders hematopoietic precursor cells more sensitive to stimulation by erythropoietin and thrombopoietin. Hence, increased red blood cell and PLT counts are observed in MPN. Literature researches reveal this mutation is present $65-97 \%$ in PV, $50-70 \%$ in ET, and 40-50\% in PMF [6, 8]. In our study JAK2-V617F mutation prevalence was 58.2\% in PV, 54.4\% in ET, and 54.5\% in PMF.

In accordance with the literature, MPN patients with JAK2-V617F mutation had higher mean age in our study (Table 1). Conducted researches also report that JAK2-V617F mutation is particularly seen in the elderly and the mean age at the diagnosis is 60 [30]. Considering age is one
Table 3: Studies investigating the effect of the presence of JAK2-V617F mutation on age and hematologic parameters in ET patients.

\begin{tabular}{|c|c|c|c|}
\hline & Mutant & Wild-type & p-Value \\
\hline \multirow[t]{2}{*}{ Heller et al. [23] } & $(n=24)$ & $(n=26)$ & \\
\hline & $\mathrm{F} / \mathrm{M}(18 / 6)$ & $\mathrm{F} / \mathrm{M}(16 / 8)$ & \\
\hline Age, year & $48(21-81)^{\star}$ & $30(11-77)^{\star}$ & 0.001 \\
\hline \multirow[t]{2}{*}{ WBC, $10^{3} / \mu \mathrm{L}$} & 9.2 & 8.8 & 0.4 \\
\hline & $(5.0-13.4)^{\star}$ & $(5.5-16.8)^{\star}$ & \\
\hline $\mathrm{Hb}, \mathrm{g} / \mathrm{dL}$ & $14.3 \pm 1.5$ & $12.9 \pm 1.4$ & 0.002 \\
\hline \multirow[t]{2}{*}{$\mathrm{PLT}, 10^{3} / \mu \mathrm{L}$} & 1070 & 1505 & 0.03 \\
\hline & $(608-3742)^{\star}$ & $(890-2240)^{\star}$ & \\
\hline \multirow[t]{2}{*}{ Cheung et al. [24] } & $(n=29)$ & $(n=31)$ & \\
\hline & F/M (19/10) & $\mathrm{F} / \mathrm{M}(17 / 14)$ & \\
\hline Age, year & $46(20-80)^{\star}$ & $41(8-77)^{\star}$ & $>0.05$ \\
\hline WBC, $10^{3} / \mu \mathrm{L}$ & $10.1 \pm 4.8$ & $7.9 \pm 3.9$ & $>0.05$ \\
\hline $\mathrm{Hb}, \mathrm{g} / \mathrm{dL}$ & $14.2 \pm 1.5$ & $13 \pm 1.7$ & 0.0426 \\
\hline $\mathrm{PLT}, 10^{3} / \mu \mathrm{L}$ & $867 \pm 201$ & $954 \pm 402$ & $>0.05$ \\
\hline \multirow[t]{2}{*}{ Antonioli et al. [25] } & $(n=74)$ & $(n=56)$ & \\
\hline & $\mathrm{F} / \mathrm{M}(62 / 12)$ & $\mathrm{F} / \mathrm{M}(49 / 7)$ & \\
\hline Age, year & $51(19-84)^{\star}$ & $48(16-81)^{\star}$ & $>0.05$ \\
\hline WBC, $10^{3} / \mu \mathrm{L}$ & $9.2 \pm 2.7$ & $8.7 \pm 2.4$ & $>0.05$ \\
\hline $\mathrm{Hb}, \mathrm{g} / \mathrm{dL}$ & $14.2 \pm 1.3$ & $13.4 \pm 1.3$ & 0.001 \\
\hline Hct, \% & $43.0 \pm 3.6$ & $40.5 \pm 3.7$ & 0.0001 \\
\hline $\mathrm{PLT}, 10^{3} / \mu \mathrm{L}$ & $846 \pm 244$ & $1014 \pm 400$ & 0.004 \\
\hline \multirow[t]{2}{*}{ Patriarca et al. [26] } & $(n=60)$ & $(n=46)$ & \\
\hline & $\mathrm{F} / \mathrm{M}(32 / 28)$ & F/M (29/17) & \\
\hline Age, year & $62(25-92)^{\star}$ & $68(25-91)^{\star}$ & $>0.05$ \\
\hline WBC, $10^{3} / \mu \mathrm{L}$ & $9.2 \pm 2.8$ & $8.1 \pm 2.0$ & $<0.03$ \\
\hline Hct, \% & $45.2 \pm 3.9$ & $42.1 \pm 4.5$ & $<0.0002$ \\
\hline $\mathrm{PLT}, 10^{3} / \mu \mathrm{L}$ & $650 \pm 145$ & $766 \pm 195$ & $<0.0006$ \\
\hline \multirow[t]{2}{*}{ Wolanskyj et al. [27] } & $(n=73)$ & $(n=77)$ & \\
\hline & $\mathrm{F} / \mathrm{M}(51 / 21)$ & $F / M(48 / 29)$ & \\
\hline \multirow[t]{2}{*}{ Age, year } & 53.5 & 42.3 & 0.02 \\
\hline & $(16.9-98.0)^{\star}$ & $(16.7-84.8)^{\star}$ & \\
\hline \multirow[t]{2}{*}{ WBC, $10^{3} / \mu \mathrm{L}$} & 10.7 & 9.1 & 0.005 \\
\hline & $(5.0-24.1)^{\star}$ & $(4.0-29.8)^{\star}$ & \\
\hline \multirow[t]{2}{*}{$\mathrm{Hb}, \mathrm{g} / \mathrm{dL}$} & 14.6 & 14.0 & 0.0002 \\
\hline & $(10.9-17.6)^{\star}$ & $(9.0-16.4)^{\star}$ & \\
\hline \multirow[t]{2}{*}{$\mathrm{PLT}, 10^{3} / \mu \mathrm{L}$} & 1000 & 1000 & 0.52 \\
\hline & $(509-3000)^{\star}$ & $(454-3460)^{\star}$ & \\
\hline \multirow[t]{2}{*}{ Our study } & $(n=49)$ & $(n=41)$ & \\
\hline & F/M (29/20) & $\mathrm{F} / \mathrm{M}(30 / 11)$ & \\
\hline Age, year & $62.0 \pm 19.3$ & $54.5 \pm 15,3$ & 0.048 \\
\hline \multirow[t]{2}{*}{$\mathrm{WBC}, 10^{3} / \mu \mathrm{L}$} & 11.1 & 9.4 & 0.227 \\
\hline & $(4.5-30.4)^{\star}$ & $(5.3-22.7)^{\star}$ & \\
\hline $\mathrm{Hb}, \mathrm{g} / \mathrm{dL}$ & $12.9 \pm 2.3$ & $12.5 \pm 1.5$ & 0.236 \\
\hline Hct, \% & $40.2 \pm 6.8$ & $38.5 \pm 4.2$ & 0.171 \\
\hline $\mathrm{PLT}, 10^{3} / \mu \mathrm{L}$ & $800.8 \pm 281.7$ & $746.8 \pm 295.0$ & 0.378 \\
\hline
\end{tabular}

* : median (min-max), others mean \pm SD. F/M, Female/Male.

of the factors increasing oxidative stress [31], we suggest that age may increase the risk of developing thrombosis and other complications by increasing the prevalence of JAK2 mutation in the pathogenesis of MPN.

In our study, similar to literature, $\mathrm{Hb}$, and Hct levels were detected to be higher in PV patients with the mutation 
Table 4: Studies investigating the effect of the presence of JAK2-V617F mutation on age and hematologic parameters in PMF patients.

\begin{tabular}{lrrr}
\hline & Mutant & Wild-type & p-Value \\
\hline ilhan et al. [28] & $(\mathrm{n}=2)$ & $(\mathrm{n}=6)$ & \\
WBC, $10^{3} / \mu \mathrm{L}$ & 30.5 & 7.2 & $\mathbf{0 . 0 4 6}$ \\
$\mathrm{Hb}, \mathrm{g} / \mathrm{dL}$ & 12.5 & 9.04 & 0.09 \\
$\mathrm{Hct}, \%$ & 38.7 & 26.05 & $\mathbf{0 . 0 4 6}$ \\
$\mathrm{PLT}, 10^{3} / \mu \mathrm{L}$ & 305.5 & 191 & 0.505 \\
Campbell et al. [29] & $(\mathrm{n}=83)$ & $(\mathrm{n}=69)$ & \\
& $\mathrm{F} / \mathrm{M}(39 / 44)$ & $\mathrm{F} / \mathrm{M}(27 / 42)$ & \\
Age, year & $64(48-77)^{\star}$ & $62(43-77)^{\star}$ & 0.3 \\
WBC, $10^{3} / \mu \mathrm{L}$ & $15.3 \pm 15.4$ & $10.1 \pm 7.9$ & $\mathbf{0 . 0 2}$ \\
Hb, g/dL & $11 \pm 2.4$ & $10.4 \pm 2.2$ & 0.1 \\
PLT, $10^{3} / \mu \mathrm{L}$ & $312 \pm 252$ & $254 \pm 203$ & 0.3 \\
Our study & $(\mathrm{n}=6)$ & $(\mathrm{n}=5)$ & \\
& $\mathrm{F} / \mathrm{M}(2 / 4)$ & $\mathrm{F} / \mathrm{M}(4 / 1)$ & \\
Age, year & $66.5 \pm 7.9$ & $55.0 \pm 8.9$ & $\mathbf{0 . 0 4 9}$ \\
WBC, $10^{3} / \mu \mathrm{L}$ & $17.3 \pm 6.1$ & $9.4 \pm 4.0$ & $\mathbf{0 . 0 3 5}$ \\
Hb, g/dL & $10.6 \pm 2.9$ & $9.9 \pm 1.9$ & 0.631 \\
Hct, \% & $34.7 \pm 10.0$ & $30.0 \pm 5.5$ & 0.371 \\
PLT, $10^{3} / \mu \mathrm{L}$ & $577.6 \pm 359.8$ & $354.7 \pm 369.3$ & 0.354 \\
\hline
\end{tabular}

* : median (min-max), others mean \pm SD. F/M, Female/Male. p-Values less than 0.05 were marked as bold.

(Table 2). The prothrombotic effect of increased Hct levels in PV is associated with substantially high thrombotic risk that is in line with blood viscosity [32]. Blood viscosity may increase thrombotic risk by several different mechanisms. In venous circulation, under low tension conditions, high Hct levels have a bigger impact on blood viscosity and further deteriorate the blood flow. An increase in red blood cell count causes platelets to move closer to vessel wall leading to PLT activation induced by tension [33]. Erythrocyte aggregation also increases the interaction of PLT and WBC with vessel wall [34].

In our study, PLT counts were found to be higher for ET patient group; however, no significant difference was observed between the groups (Table 3). In ET patients, thrombocytosis leads to hemorrhagic events and thrombotic events [35]. At the present time, it is believed that hemorrhage in ET is of multifactorial etiology [10]. For some patients hemorrhage may be linked to acquired von Willebrand Syndrome occurring in thrombocytosis, as a matter of fact, large "von Willebrand factor" (vWF) multimers are rapidly consumed in plasma [36]. Therefore when PLT count is higher than $1000 \times 109 / \mathrm{L}$; vWF antigen, FVIII, and Ristocetin cofactor activity tests should be carried out, treatment should be planned out accordingly [10].

In the presence of extremely high PLT counts, thrombocytosis should be treated due to major bleeding risk. However since treatment itself might cause potential complications, we believe cases should be managed according to their thrombosis risks.

In accordance with the literature, our study also found significantly higher WBC counts in mutation positive group (Table 4). The high level WBC count is associated with extramedullary hematopoiesis and leukoerythroblastic state. An increase in WBC is a risk factor for thrombosis [37]; in the presence of the mutation, phenotype changes are shown for WBC. Due to this phenotype transformation, intracellular elastase level is significantly increased by membrane $\beta 2$ integrin $\mathrm{CD} 11 \mathrm{~b}$ and leukocyte alkaline phosphatase expression [38]. An increase in plasma concentrations of elastase and myeloperoxidase causes in vivo neutrophil activation. Hypersecretion of adhesion molecules on the neutrophil membrane (integrins and selectins) increases the adhesion of neutrophils to endothelial cells and PLT. Cell-cell interaction increases the expression of prothrombotic units, leads to release of reactive oxygen species and intragranular proteases like elastase and cathepsin $\mathrm{G}$ from activated neutrophils [39]. The interaction of neutrophil and PLT is controlled by a cascade. P-selectin of the thrombocyte binds to P-selectin glycoprotein ligand-1 of neutrophil. The interaction between activated neutrophils and PLT leads to neutrophil-PLT aggregate formation. These are sensitive markers of PLT activation and have been shown to increase in severe pathological conditions related to thrombotic tendency [40].

The limitations of our study are that it is retrospective, single centered, a limited number of patients and limited hematological parameters were evaluated.

In conclusion; there has been great progress in the research regarding the role of JAK2-V617F mutation in MPN pathogenesis and its clinical implications. In the light of these advancements; this mutation has been listed as a diagnostic criterion and there has been increasing interest in molecularly targeted mutant JAK2 inhibitors and the new medication affecting JAK-STAT pathway for treatment. Consequently; all cases with suspected MPN should absolutely be screened for JAK2-V617F mutation. Considering the association between the mutation presence and hematologic parameters; we believe possible complications of the patients with the mutation can be prevented by close monitoring and treatment planning.

Research funding: None declared.

Author Contributions: Concept: Murat Aksit, Giray Bozkaya; Design: Murat Aksit, Giray Bozkaya, Nuriye Uzuncan, Sibel Bilgili, Can Ozlu; Data Collection or Processing: Murat Aksit, Giray Bozkaya, Can Ozlu; Analysis or Interpretation: Murat Aksit, Giray Bozkaya, Nuriye Uzuncan, Sibel Bilgili, Merve 
Zeytinli Aksit; Literature Search: Murat Aksit, Giray Bozkaya; Writing: Murat Aksit, Giray Bozkaya, Merve Zeytinli Aksit.

Conflict of Interest: The authors of this paper have no conflicts of interest, including specific financial interests, relationships, and/or affiliations relevant to the subject matter or materials included.

Ethics: Ethics Committee Approval: University of Health Sciences Bozyaka Training and Research Hospital Ethic Committee 09.09.2014/07, Informed Consent: Retrospective study.

\section{References}

1. Baxter EJ, Scott LM, Campbell PJ, East C, Fourouclas N, Swanton S, et al. Acquired mutation of the tyrosine kinase JAK2 in human myeloproliferative disorders. Lancet 2005;365:1054-61.

2. Marchetti M, Falanga A. Leukocytosis, JAK2V617F mutation, and hemostasis in myeloproliferative disorders. Pathophysiol Haemostasis Thrombosis 2008;36:148-59.

3. Mahfouz RA, Hoteit R, Salem Z, Bazarbachi A, Mugharbel A, Farhat F, et al. JAK2 V617F gene mutation in the laboratory workup of myeloproliferative disorders: experience of a major referral center in Lebanon. Genet Test Mol Biomarkers 2011;15:263-5.

4. Nielsen C, Birgens HS, Nordestgaard BG, Bojesen SE. Diagnostic value of JAK2 V617F somatic mutation for myeloproliferative cancer in 49488 individuals from the general population. $\mathrm{Br}$ J Haematol 2013;160:70-9.

5. Dupont S, Massé A, James C, Teyssandier I, Lécluse $Y$, Larbret F, et al. The JAK2 617V $>\mathrm{F}$ mutation triggers erythropoietin hypersensitivity and terminal erythroid amplification in primary cells from patients with polycythemia vera. Blood 2007;110: 1013-21.

6. Tefferi A, Lasho TL, Gilliland G. JAK2 mutations in myeloproliferative disorders. N Engl J Med 2007;356:444-5.

7. Kaushansky K. The chronic myeloproliferative disorders and mutation of JAK2: Dameshek's 54 years old speculation comes of age. Best Pract Res Clin Haematol 2007;20:5-12.

8. Kralovics R, Passamonti F, Buser AS, Teo SS, Tiedt R, Passweg JR, et al. A gain of function mutation of JAK2 in myeloproliferative disorders. N Engl J Med 2005;352:1779-90.

9. Tefferi A. Polycythemia vera and essential thrombocythemia: 2012 update on diagnosis, risk stratification, and management. Am J Haematol 2012;87:285-93.

10. Elliott MA, Tefferi A. Thrombosis and haemorrhage in polycythaemia vera and essential thrombocythaemia. $\mathrm{Br}$ J Haematol 2005;128:275-90.

11. Marchioli R, Finazzi G, Landolfi R, Kutti J, Gisslinger H, Patrono C, et al. Vascular and neoplastic risk in a large cohort of patients with polycythemia vera. J Clin Oncol 2005;23:2224-32.

12. Cervantes F, Alvarez-Larrán A, Arellano-Rodrigo E, Granell M, Domingo A, Montserrat $E$. Frequency and risk factors for thrombosis in idiopathic myelofibrosis: analysis in a series of 155 patients from a single institution. Leukemia 2006;20: 55-60.
13. Barbui T, Carobbio A, Cervantes F, Vannucchi AM, Guglielmelli P, Antonioli E, et al. Thrombosis in primary myelofibrosis: incidence and risk factors. Blood 2010;115:778-82.

14. Tefferi A, Rumi E, Finazzi G, Gisslinger H, Vannucchi AM, Rodeghiero F, et al. Survival and prognosis among 1545 patients with contemporary polycythemia vera: an international study. Leukemia 2013;27:1874-81.

15. Chim CS, Kwong YL, Lie AK, Ma SK, Chan CC, Wong LG, et al. Longterm outcome of 231 patients with essential thrombocythemia: prognostic factors for thrombosis, bleeding, myelofibrosis, and leukemia. Arch Intern Med 2005;165:2651-8.

16. Palandri F, Polverelli N, Catani L, Ottaviani E, Baccarani M, Vianelli N. Impact of leukocytosis on thrombotic risk and survival in 532 patients with essential thrombocythemia: a retrospective study. Ann Hematol 2011;90:933-8.

17. Landolfi R, Di Gennaro L, Barbui T, De Stefano V, Finazzi G, Marfisi $R$, et al. European Collaboration on Low-Dose Aspirin in Polycythemia Vera (ECLAP). Leukocytosis as a major thrombotic risk factor in patients with polycythemia vera. Blood 2007;109: 2446-52.

18. Karkucak M, Yakut T, Ozkocaman V, Ozkalemkas F, Ali R, Bayram $M$, et al. Evaluation of the JAK2-V617F gene mutation in Turkish patients with essential thrombocythemia and polycythemia vera. Mol Biol Rep 2012;39:8663-7.

19. Ünal K, Erdoğan S, Yılmaz FM. JAK 2 V617F gen mutasyon sıklığı ve tam kan sayımı parametreleri ile ilişkisi. Turk J Biochem 2014;39: 93-8.

20. Speletas M, Katodritou E, Daiou C, Mandala E, Papadakis E, Kioumi A, et al. Correlations of JAK2-V617F mutation with clinical and laboratory findings in patients with myeloproliferative disorders. Leuk Res 2007;31:1053-62.

21. Duletić AN, Dekanić A, Hadzisejdić I, Kusen I, Matusan-Ilijas K, Grohovac D, et al. JAK2-v617F mutation is associated with clinical and laboratory features of myeloproliferative neoplasms. Coll Antropol 2012;36:859-65.

22. Demir AK, Atay MH, Kelkitli E, Turgut Kurt Y, Özatlı D, Turgut M. Kronik miyeloproliferatif Hastalıklarda JAK2V617F mutasyonu JAK2V617F mutation in chronic myeloproliferative disorders. J Contemp Med 2013;3:101-7.

23. Heller PG, Lev PR, Salim JP, Kornblihtt LI, Goette NP, Chazarreta $\mathrm{CD}$, et al. JAK2V617F mutation in platelets from essential thrombocythemia patients: correlation with clinical features and analysis of STAT5 phosphorylation status. Eur J Haematol 2006; 77:210-6.

24. Cheung B, Radia D, Pantelidis P, Yadegarfar G, Harrison C. The presence of the JAK2 V617F mutation is associated with a higher haemoglobin andincreased risk of thrombosis in essential thrombocythaemia. Br J Haematol 2006;132:244-5.

25. Antonioli E, Guglielmelli P, Pancrazzi A, Bogani C, Verrucci M, Ponziani V, et al. Clinical implications of the JAK2 V617F mutation in essential thrombocythemia. Leukemia 2005;19: 1847-9.

26. Patriarca A, Pompetti F, Malizia R, Iuliani O, Di Marzio I, Spadano $A$, et al. Is the absence of JAK2 mutation a risk factor for bleeding in essential thrombocythemia? An analysis of 106 patients. Blood Transfus 2010;8:21-7.

27. Wolanskyj AP, Lasho TL, Schwager SM, McClure RF, Wadleigh M, Lee SJ, et al. JAK2 mutation in essential thrombocythaemia: 
clinical associations and long-term prognostic relevance. $\mathrm{Br} J$ Haematol 2005;131:208-13.

28. Ilhan G, Karakus S, Sahin FI. JAK 2V617F mutation: frequency and relation to clinical and laboratory features of BCR-ABL negative myeloproliferative diseases. Int J Hematolo Oncolo 2012;22: 77-84.

29. Campbell PJ, Griesshammer M, Döhner K, Döhner H, Kusec R, Hasselbalch HC, et al. V617F mutation in JAK2 is associated with poorer survival in idiopathic myelofibrosis. Blood 2006;107: 2098-100.

30. Srour SA, Devesa SS, Morton LM, Check DP, Curtis RE, Linet M, et al. Incidence and patient survival of myeloproliferative neoplasms and myelodysplastic/myeloproliferative neoplasms in the United States, 2001-2012. Br J Haematol 2016;174: 382-96.

31. Liguori I, Russo G, Curcio F, Bulli G, Aran L, Della-Morte D, et al. Oxidative stress, aging, and diseases. Clin Interv Aging 2018;13: 757-72.

32. Walton BL, Lehmann M, Skorczewski T, Holle LA, Beckman JD, Cribb JA, et al. Elevated hematocrit enhances platelet accumulation following vascular injury. Blood 2017;129: 2537-46.

33. Skorczewski T, Erickson LC, Fogelson AL. Platelet motion near a vessel wall or thrombus surface in two-dimensional whole blood simulations. Biophys J 2013;104:1764-72.
34. Pearson MJ, Lipowsky HH. Influence of erythrocyte aggregation on leukocyte margination in postcapillary venules of rat mesentery. Am J Physiol Heart Circ Physiol 2000;279:H1460-71.

35. Griesshammer M, Struve S, Harrison CM. Essential thrombocythemia/polycythemia vera and pregnancy: the need for an observational study in Europe. Semin Thromb Hemost 2006;32:422-9.

36. Landolfi R, Cipriani MC, Novarese L. Thrombosis and bleeding in polycythemia vera and essential thrombocythemia: pathogenetic mechanisms and prevention. Best Pract Res Clin Haematol 2006; 19:617-33.

37. Landolfi R, Di Gennaro L, Falanga A. Thrombosis in myeloproliferative disorders: pathogenetic facts and speculation. Leukemia 2008;22:2020-8.

38. Falanga A, Marchetti M, Evangelista V, Vignoli A, Licini M, Balicco $M$, et al. Polymorphonuclear leukocyte activation and hemostasis in patients with essential thrombocythemia and polycythemia vera. Blood 2000;96:4261-6.

39. Falanga A, Marchetti M, Barbui T, Smith CW. Pathogenesis of thrombosis in essential thrombocythemia and polycythemia vera: the role of neutrophils. Semin Hematol 2005;42: 239-47.

40. Krishnamurthy VR, Sardar MY, Ying Y, Song X, Haller C, Dai E, et al. Glycopeptide analogues of PSGL-1 inhibit P-selectin in vitro and in vivo. Nat Commun 2015;6:6387. 